\title{
IНФЕКЦІЙНI РЕСПІРАТОРНІ УСКЛАДНЕННЯ ТА ЇХ МІКРОБІОЛОГІЧНА ХАРАКТЕРИСТИКА У ДІТЕЙ КАРДІОХІРУРГІЧНОГО ПРОФІЛЮ
}

\author{
Р. М. Ємець ${ }^{1}$, Г. В. Філоненко ${ }^{1}$, В. А. Жовнір ${ }^{1}$, Д. Л. Кирик ${ }^{2}$
}

${ }^{1}$ Науково-практичний медичний центр дитячої кардіології та кардіохірургії МОЗ України, м. Київ

${ }^{2}$ Національна медична академія післядипломної освіти імені П. Л. Шупика МОЗ України, м. Київ

\section{THE INFECTION RESPIRATORY COMPLICATIONS AND THEIR MICROBIOLOGICAL CHARACTERISTIC IN CHILDREN OF CARDIOSURGICAL PROFILE}

\author{
R. M. Emets ${ }^{1}$, G. V. Filonenko ${ }^{1}$, V. A. Zhovnir ${ }^{1}$, D. L. Kyryk ${ }^{2}$ \\ ${ }^{1}$ Scientific-Practical Medical Centre of Pediatric Cardiology and Cardiosurgery, Kyiv \\ ${ }^{2}$ Shupyk National Medical Academy of Postgraduate Education, Kyiv
}

\begin{abstract}
Реферат
Проаналізовані результати мікробіологічних досліджень мокротиння, одержаного при бронхофріброскопії у 24 пацієнтів, оперованих з приводу вроджених вад серця (ВВС). У 16 (66,6\%) пацієнтів виявлені мікробні асоціації, у 5 (20,8\%)- збудники інфекційних ускладнень. Збудники в монокультурі представлені грамнегативними штамами - у 45 (50,6\%) хворих, у тому числі 29 штамів неферментуючих, у 16 - родини Enterobacteriaceae. 3 грампозитивних штамів переважали Staphylococcus epidermidis- y 14 (15,7\%) хворих, Staphylococcus haemolyticus- у $13(14,6 \%)$.

Вивчення структури збудників, аналіз резистентності мікроорганізмів до антимікробних препаратів та визначення їх молекулярно-генетичних особливостей є важливим етапом фрормування тактики антибактеріальної терапії, що дозволяє зменшити ризик виникнення інфекційних ускладнень після операцій з приводу ВВС.

Ключові слова: вроджені вади серця; хірургічне лікування; інфекційні ускладнення.

Abstract

Results of microbiological investigations of sputum, obtained while bronchofibroscopy conduction in 24 patients, operated for the inborn heart failures, were analyzed. In $16(66.6 \%)$ patients microbial associations were revealed, in $5(20.8 \%)$ - the infection complications vectors. The causative agents in monoculture were presented by gramm-negative stamms - in $45(50.6 \%)$ patients, including 29 stamms of nonenzymating, in 16 - of Enterobacteriaceae family. In gramm-positive stamms Staphylococcus epidermidis prevailed-in 14 (15.7\%) patients, Staphylococcus haemolyticus- in $13(14.6 \%)$.

Studying of the causative agents structure, analysis of resistance of microorganisms towards antimicrobic preparations and determination of their molecular-genetic peculiarities constitutes significant stage of formation of the antibacterial therapy tactics, permitting the risk reduction for the postoperative infection morbidity after procedures, made for the inborn heart failure.

Keywords: inborn heart failure; surgical treatment; infection complications.
\end{abstract}

Нозокоміальна пневмонія (НП) $€$ однією з актуальних проблем сучасної інтенсивної терапії. Вона може виникати в період проведення штучної респіраторної підтримки (вентилятор - асоційована пневмоніяВАП) у пацієнтів за різних варіантів критичних станів. У відділеннях реанімації та інтенсивної терапії (BPIT) ВАП - друге за частотою інфекційне ускладнення у дітей раннього віку.

Поширення ВАП у дитячих ВРІT у пацієнтів, яким здійснюють штучну вентиляцію легень (ШВЛ), становить від 3 до 10\% [1]. У дітей, оперованих 3 приводу ВВС, частота ВАП становить від 9 до 21\%. Частота ВАП у дітей раннього віку становить 6 11 епізодів на 1000 днів ШВЛ в усіх пацієнтів ВРІТ [2, 3]. Одним 3 домінуючих збудників ВАП як у дорос- лих, так і дітей є мікроорганізми роду Pseudomonas. Частота виявлення P. aeruginosa $з$ ендотрахеального аспірату при ВАП у дітей після кардіохірургічних операцій з приводу ВBC досягає 45\% [2, 4 - 6]. Основні проблеми терапії ускладнень пов'язані $з$ природною резистентністю мікроорганізмів роду Pseudomonas як збудника нозокоміальних інфекцій до більшості антибіотиків, а також здатністю набувати резистентність під час антибактеріальної терапії.

Впровадження у практику роботи кардіохірургічного стаціонару науково обгрунтованої системи стратегії та тактики епідеміологічного нагляду забезпечує реальну основу створення та підтримки умов, що зумовлюють ефективне попередження післяопераційних ускладнень бактеріальної природи та успішне лікування дітей з приводу ВВС [7 - 9].

Мета роботи: провести аналіз збудників інфекційних ускладнень у мокротинні, взятому з слизової оболонки бронхів у дітей, оперованих 3 приводу ВВС, яких протягом тривалого часу лікували у ВРIT.

\section{МАТЕРІАЛИ I МЕТОДИ ДОСЛІДЖЕННЯ}

Проведене бактеріологічне дослідження у 24 пацієнтів, оперованих 3 приводу ВВС, у яких припускали наявність інфекційних респіраторних ускладнень. В усіх пацієнтів здійснено радикальну корекцію BBC. Наявність запальних ускладнень 3 ураженням органів дихання встановлювали на основі оцінки клінічного стану пацієнта (підвищення 
температури тіла, кашель, наявність хрипів тощо), змін лабораторних показників (загальний аналіз крові), результатів інструментальних методів дослідження (рентгенографії, бронхофіброскопіi). Пацієнтам проведена санаційна бронхофіброскопія, робили змиви мокротиння 3 слизової оболонки головних бронхів під час лікування у ВРІТ [10].

Вік пацієнтів від 0,67 до 4,25 року, медіана 2,5 міс, маса тіла від 4,25 до 8,9 кг, медіана 5,1 кг; 18 (75\%) пацієнтів - чоловічої статі, 6 (25\%) - жіночої. Тривалість лікування у стаціонарі від 24 до 85 днів, у середньому $(40,3 \pm 14,4)$ дня. Кардіологічний діагноз у 15 (62,5\%) пацієнтів характеризувався надмірним кровотоком у малому колі кровообігу, у 9 (37,5\%) були різні діагнози, в тому числі обструкція лівих відділів серця на рівні дуги аорти (коарктація) - у 3 (12,5\%), на рівні клапана аорти (стеноз)- в 1 (4,1\%), транспозиція магістральних судин - у 3 (12,5\%), тетрада Фалло - у 2 (8,3\%). При гіперволемії малого кола кровообігу дефекти міжшлуночкової перегородки (різних розмірів) відзначені у 9 пацієнтів, повна атріовентрикулярна комунікація- у 4, тотальне аномальне дренування легеневих вен-у 2. У 18 (75\%) пацієнтів оперативні втручання виконані в умовах штучного кровообігу, у 6 (25\%)- без такого. У 9 (37,5\%) пацієнтів здійснені повторні оперативні втручання протягом періоду однієї госпіталізації.

Проводили змиви мокротиння 3 дихальних шляхів (головних бронхів) через робочий канал педіатричного бронхофіброскопа виробництва фірми Olympus, модель BF type ХР 60, зовнішній діаметр 2,8 мм. Змиви проводили шляхом введення стерильного ізотонічного розчину натрію хлориду через робочий канал бронхоскопа в об'ємі 2-5 мл, залежно від віку пацієнта, у кожний головний бронх окремо.

Дослідження біологічного матеріалу та інтерпретацію результатів проводили відповідно до діючих вимог, ідентифікацію виділених мікроорганізмів - за загальноприйнятими бактеріологічними методами, дотримуючись класифікації Бергі (1997). Для ідентифікації і визначення чутливості клінічно значущих мікроорганізмів до антибіо- тиків використовували бактеріологічний аналізатор VITEC 2 COMPACT (bioMerieux).

Статистична обробка даних проведена за допомогою програм WHONET 5,6 та Statistica 6,0. Статистичну значущість різниці показників тестували за критерієм Фішера, відмінності вважали статистично значущими при $\mathrm{p}<0,05$.

\section{РЕЗУЛЬТАТИ \\ ТА ÏХ ОБГОВОРЕННЯ}

Трахеобронхіт виник у 5 (25\%) пацієнтів, пневмонія - у 9 (37,5\%), поєднання вираженого трахеобронхіту та пневмонії однієї або двох легень - у 9 (37,5\%). В обстежених хворих виділені 89 (87,5\%) культур, мікробні асоціації - у 16 (66,6\%), збудники у монокультурі - у 5 (20,8\%), нормальна мікрофлора верхніх дихальних шляхів - в 1 (4,1\%), у 2 (8,3\%) хворих мікрофлора не виявлена. Збудники інфекційних ускладнень у дітей, оперованих з приводу ВВС, представлені грамнегативними штамами бактерій (ГНБ) - у 45 (50,6\%), в тому числі 29 штамів неферментуючих, 16- родини Enterobacteriaceae (див. рисунок).

3 неферментуючих ГНБ найчастіше виявляли в біологічному матеріалі P. aeruginosa - 12 штамів, що становило 13\% в загальній структурі умовно патогенних мікроорганізмів (УПМ) у 6 пацієнтів. Stenotrophomonas maltophilia виявлені у 4 (4,5\%) хворих, Chryseobacter indologenes- y 4 (4,5\%), Moraxella catarrhalis- y 4 (4,5\%), Chryseomonas luteula- y 2 (2,5\%).

Родина ентеробактерій представлена кількома родами: Citrobacter, Enterobacter, Escherichia, Klebsiella. 3 них переважали штами К. pneumoniae - 10 (11,2\%), значно рідше виявляли штами родів Enterobacter, Escherichia та Citrobacter- відповідно 2 (2,2\%), 2 $(2,2 \%)$ та 2 (2,2\%).

Грампозитивні штами бактерій (ГПБ) виявлені у 40 (44,9\%) спостереженнях, в тому числі 4 штами- коагулазопозитивні, 27 - коагулазонегативні коки, 4 штами- каталазопозитивні, 27- каталазонегативні коки. 3 коагулазопозитивних стафілококів найчастіше виявляли патогенний стафілокок - 4 штами, що становило 4,5\% в загальній структу-

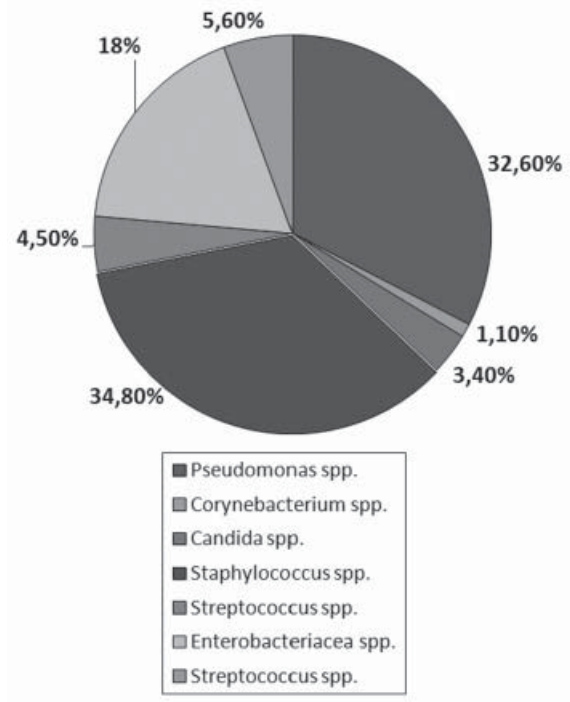

Структура мікрофрлори, виділеної у дітей, оперованих з приводу ВВС.

рі УПМ. 3 коагулазонегативних стафілококів Staphylococcus epidermidis виділений у 14 (15,7\%) спостереженнях, Staphylococcus haemolyticus- y 13 (14,6\%). 3 каталазонегативних коків переважали Enterococcus spp. -5 $(5,6 \%)$ штамів та Streptococcus spp.4 (4,5\%).

При аналізі чутливості Р. aeruginosa до антибактеріальних препаратів виявлено невисоку частоту чутливих штамів практично до всіх тестованих антибіотиків - від 19,6 до 100\%, за винятком колістину та фосфоміцину. До них були чутливі всі виділені штами. До аміноглікозидних антибіотиків збудники виявляли різну чутливість. Так, до тобраміцину стійкими були 26,5\% штамів, до амікацину та нетилміцину 19,6\%. 3 $\beta$-лактамних антибіотиків цефазолін був найменш активним.

При аналізі чутливості клінічних штамів K. pneumoniae встановлено, що резистентність до окремих груп $\beta$-лактамних антибіотиків не різнилася і була дуже низькою. Аміноглікозиди також виявляли відносно невисоку активність до K. pneumoniae. Нечутливими до амікацину, нетилміцину та тобраміцину були 60\% клінічних штамів. Резистентність штамів K. pneumoniae до фторхінолонів (ципрофлоксацин, левофлоксацин, офлоксацин) становила 80\%.

Резистентність S. haemolyticus до пеніциліну виявилася найбільшою, нечутливими до нього були 81,3\% 
штамів. Найбільшу активність до S. haemolyticus проявляли глікопептиди (ванкоміцин, тейкопланін) та лінезолід, до яких були чутливі всі штами.

Результати мікробіологічного дослідження певним чином пояснюють ускладнений перебіг післяопераційного періоду і необхідність проведення тривалої респіраторної підтримки у таких пацієнтів. Тривалість (медіана) респіраторної підтримки у пацієнтів при інфекційних респіраторних ускладненнях, що потребували проведення бронхофіброскопії, становила від 59,7 до 458,5 год, медіана 156,5 год, що достовірно більше аналогічного показника у пацієнтів, оперованих з приводу ВВС, за відсутності таких ускладнень - від 5 до 45 год, медіана 17 год ( $<0,05)$. Тривалість лікування у ВРІТ пацієнтів з інфекційними респіраторними ускладненнями також була достовірно більша - від 10,7 до 27,2 дня, медіана 18 днів; за відсутності ускладнень - від 2 до 5 днів, медіана 3 дні $(\mathrm{p}<0,05)$.

Вивчення структури збудників різних біотопів УПМ, аналіз резистентності мікроорганізмів до антимікробних препаратів та визна- чення їх молекулярно-генетичних особливостей $€$ важливим етапом формування тактики антибактеріальної терапії інфекційних ускладнень. Для адекватного режиму антибіотикопрофілактики, крім природної резистентності мікроорганізмів, необхідно мати на увазі збільшення частоти набутої резистентності госпітальних штамів. Саме ГНБ характеризуються множинними та складними механізмами антибіотикорезистентності [7].

Наші дані відповідають спостереженням інших авторів про значне поширення MRSE 3 високим рівнем резистентності у дітей $[8,9]$. Це потребує особливої настороженості, оскільки використання класичних методів ідентифікації стафілококів дозволяє диференціювати тільки два види MRSE, для яких чутливість до антибактеріальних препаратів у багатьох біологічних матеріалах визначають рідко у зв'язку з їх низькою етіологічною значущістю. У той же час, застосування автоматизованих систем, в яких одночасно $з$ ідентифікацією визначають чутливість ізолятів до широкого спектру антимікробних препаратів, дозволяє виявляти резистентні штами
MRSE. При цьому резистентні коагулазонегативні стафілококи частіше оцінюють як діагностично значущі для даного пацієнта. Крім того, їх розглядають як фактор колонізації внутрішньолікарняними штамами та імовірний резервуар генів резистентності для коагулазопозитивних стафілококів $[3,5,6]$.

\section{висновки}

1. Інфекційне ураження органів дихальної системи частіше виникае у пацієнтів, оперованих 3 приводу ВBC з збагаченим кровотоком у судини легень.

2. Етіологічне визначення збудників таких інфекційних ускладнень важливе для їх подальшої терапії.

3. Впровадження в практику роботи кардіохірургічного стаціонару науково обгрунтованої системи стратегії та тактики епідеміологічного нагляду забезпечує реальну основу створення та підтримки умов для ефективного попередження інфекційних респіраторних ускладнень після операції та успішного лікування новонароджених і дітей першого року життя в кардіохірургічному стаціонарі.

\section{REFERENCES}

1. Lobacheva GV, Popov DA, Rakhimov AA, Kolesnikova EA. IVLassotsiirovannye pnevmonii $\mathrm{V}$ kardioreanimatsionnom otdelenii. Klinicheskaya fiziologiya krovoobrashcheniya. 2014;(3):72-6. [In Russian].

2. Hortal J, Giannella M, Perez MJ, Barrio JM, Desco M, Bouza E, Munoz P. Incidence and risk factor for ventilator-associated pneumoniae after major heart surgery. Care Med. 2009;35(9):1518-25.

3. Zhang J, Yuan Y, Li P, Wang T, Gao J, Yao J, Li S. Postoperative nosocomial infections among children with congenital heart disease. Pak J Med. Sci. 2014;30(3):554-7. doi:10.12669/pjms/303.4648.

4. Popov DA, Vostrikova TYU. Diagnostika i antimikrobnaya terapiya pnevmoniy, obuslovlennykh dlitel'noy IVL posle kardiokhirurgicheskikh operatsiy. Anesteziologiya i reanimatologiya. 2010;(5):72-7. [In Russian].

5. Filonenko HV, Salamanina AO, Kyryk DL. Rol nefermentuiuchykh mikroorhanizmiv v etiolohii infektsiinykh uskladnen u ditei z vrodzhenymy vadamy sertsia. Lviv: SPOLOM; 2016. 102-3. [In Ukrainian].

6. Custovic A, Smajlovic J, Hadzic S, Ahmetagic S, Tihic N, Hadzic H. Epidemiological surveillance of bacterial nosocomial infections in the surgical intensive care unit. Mater Sociomed. 2014;26(1):7-11. doi: $10.5455 / \mathrm{msm}$. - 2014. - 26.7-11.

7. Filonenko HV, Salamanina AO, Kyryk DL. Monitorynh mikrobiolohichnoho peizazhu u ditei z vrodzhenymy vadamy sertsia. Visnyk sertsevo-sudynnoi khirurhii. 2016;1(vypusk 24):86-8. [In Ukrainian]

8. Zubkov VV, Lyubasovskaya LA, Ryumina II, Priputnevich TV, Ankirskaya AS, Tyutyunnik VL. Mikrobiologicheskiy monitoring $\mathrm{V}$ sisteme infektsionnogo kontrolya neonatalnykh statsionarov. Rossiyskiy vesnik perinatologii i pediatrii. 2014;(1):51-6. [In Russian].

9. Orlova OA, Akimkin VG. Mikrobiologicheskiy monitoring IVL- assotsiirovannykh infektsiy dykhatel'nykh putey. Epidemiologiya i infektsionnye bolezni. 2015;(20):8-13. [In Russian]

10. Yemets RM, Chernyshuk SS, Zhovnir VA. Dosvid zastosuvannia bronkhoskopii pry likuvanni ditei iz vrodzhenymy vadamy sertsia. Visnyk sertsevo-sudynnoi khirurhii. 2013;1(vypusk 21):108-11. [In Ukrainian]. 